\title{
Effective energy planning for improving the enterprise's energy performance
}

\author{
Carmen PĂUNESCU \\ The Bucharest University of Economic Studies, Bucharest, Romania \\ carmen.paunescu@ase.ro
}

\section{Laura BLID}

The Bucharest University of Economic Studies, Bucharest, Romania

\begin{abstract}
The global pressing need to protect the environment, save energy and reduce greenhouse gas emissions worldwide has prompted the enterprises to implementing both individual energy saving measures and a more systematic approach to improve the overall enterprise's energy performance. Energy management is becoming a priority as enterprises strive to reduce energy costs, conform to regulatory requirements, and improve their corporate image. As such, enterprises are encouraged to manage their energy related matters in a systematic manner and a more harmonized way, to ensure continual improvement on their energy efficiency. Despite the increasing interest in energy management standards, a gap persists between energy management literature and current implementation practices. The release of the ISO 50001 international standard was meant to help the organizations develop sound energy management systems and effective process-based energy management structures that could be recognized through third-party certification. Building on the energy management literature and energy management standards, the current paper presents the essential steps the enterprises should take to practically design a sustainable energy management system. Also, by using multiple case studies of enterprises that have implemented an ISO 50001 energy management system, it introduces a structured approach that companies can use to effectively develop their energy planning and improve energy performance. The key components of the enterprise's energy planning are discussed, as well as practical examples of energy objectives and performance indicators from various industries are offered. The paper shows that by establishing an effective energy planning system, this will efficiently meet demands for achieving energy performance indicators and international certification.
\end{abstract}

Keywords: ISO 50001, energy management system, energy planning, energy objectives, energy performance indicators, energy action plan.

Please cite the article as follows: Păunescu, C. and Blid, L. (2016), "Effective energy planning for improving the organization's energy performance”, Management \& Marketing. Challenges for the Knowledge Society, Vol. 11, No. 3, pp. 513-531. DOI: 10.1515/mmcks-2016-0013

\section{Introduction}

Organizations worldwide are currently facing big challenges in terms of managing energy performance. These are ranging from increasing need of renewable energy use, reducing energy costs, reducing carbon emissions and protecting the environment, up to ensuring transparency and reduction of energy consumption, and improving compliance with energy legislation (Bonacina et al., 2015; International Organization for Standardization, 2011). Enterprises are keen to identify the most 
cost-effective techniques to increase their energy efficiency and secure energy use (Vikhorev et al., 2013). The global pressing needs have prompted the enterprises to implementing both individual energy saving measures and a more systematic approach to improve the overall enterprise's energy performance and increase its competitiveness (Lee and Cheng, 2016; OGP/IPIECA, 2013; Schneider Electric, 2012).

As the focus on energy continues to sharpen in Europe and worldwide due to economic or environmentally driven factors, energy management systems such as the ISO 50001 energy management system are more and more well regarded by enterprises as they enable them to effectively manage their energy use, consumption, efficiency and performance (Dzene, 2015; Brown and Desai, 2014). ISO 50001 is a globally accepted framework for managing energy, providing general energy management system requirements and guidelines for enterprises to increase energy efficiency, reduce costs, and improve environmental performance (ISO 50001:2011). Many industries have already adopted the ISO 50001 international standard, but the process is too slow for many of them (Javied, 2015). The standard was developed to assist the companies in their efforts to manage their energy related matters in a systematic manner and a more harmonized way (International Organization for Standardization, 2015; The Hong Kong Electronic Industries Association-HKEIA, 2013).

Already existing management structures and a strong culture of systematic process management developed through implementation of ISO 9001 model of quality management system and ISO 14001 model of environment management system make it easier for enterprises to integrate energy management (Karcher and Jochem, 2015). Also, harmonized standards for implementation across the enterprise together with a logical and consistent methodology for identifying and implementing improvements will guarantee company's sustainability and increase its competitiveness.

By designing and implementing sound energy management systems and effective process-based energy management structures, enterprises will demonstrate care about continual improvement of their energy performance and also about energy security (Brown and Desai, 2014; Gopalakrishnan et al., 2014). Although, the achievement of ISO 50001 certification will impact incrementally organization's financial performance on longer term (Majerník et al., 2015; Pham, 2015).

Despite the increasing interest in energy management standards, a gap persists between energy management literature and current implementation practices. Building on the energy management literature and energy management standards, in the paper we introduce the essential steps the enterprises should take to practically design a sustainable energy management system. Also, by using multiple case studies of enterprises that have introduced an ISO 50001 energy management system, the paper presents a structured model that companies can use to effectively develop their energy planning and improve energy performance. Key figures about ISO 50001 energy management system certifications worldwide are presented. The key components of the enterprise's energy planning are introduced, as well as practical examples of energy objectives and performance indicators from various industries are offered. 


\section{Defining the energy management system}

\section{What is an energy management system?}

Energy management is a term that has a number of meanings in the literature, but for the purpose of this paper we are mainly concerned with the one that relates to improving energy use, consumption and performance of an enterprise. We regard also energy management as a key to save energy in an enterprise and to enhance continuously energy efficiency.

In the acceptance of the ISO 50001 international standard, energy management refers to the systematic procurement, conversion, distribution and utilization of energy in order to achieve energy objectives and performance indicators. An energy management system (EnMS) is a performance management system that enables employees, managers and enterprises to plan, make decisions, and take effective action to better manage energy use, consumption and costs (International Organization for Standardization, 2015; TÜV UK Ltd, 2013; ISO 50001:2011). It establishes the general framework and specific requirements and conditions for enterprises to manage effectively energy (TÜV UK Ltd, 2013; ISO 50004:2011).

The ISO 50001 energy management standard outlines the specifications for any organization in establishing, implementing, maintaining and improving an energy management system through a systematic approach which will achieve continuous improvement of the enterprises' energy performance (Anisimova, 2013). It helps an enterprise to set energy objectives and targets and to monitor, measure, and analyze energy performance, irrespective of the enterprise's geographical, cultural or social conditions.

An energy management system supports enterprises in making better use of their existing energy consuming assets as well as reinforces good energy management behaviors. It facilitates communication on the management of energy resources and identifies the needs for implementation of new energy-efficient technologies. An energy management system also alerts the enterprises to significant deviations from energy baselines and targets.

The application of the ISO 50001 standard can be tailored to suit the specific needs or requirements of any enterprise, irrespective of the energy management system's complexity, degree of documentation used, and the amount of resources required or available. ISO 50001 outlines rules and requirements for its implementation, but does not impose any requirements for energy performance, nor the obligations to which an enterprise must comply in order to meet its legal and other requirements (ISO 50004:2011).

\section{Key figures on ISO 50001 worldwide and in Romania}

The organizations' interest in achieving ISO 50001 certification for their energy management system has increased tremendously worldwide since the release of the standard in 2011, with the most dominant trend line in Europe, followed by East Asia and Pacific (Table 1 and Figure 1). This can be explained, on one hand, by the great benefits acknowledged by the enterprises which implemented the standard, resulting in significant energy cost savings over the years or enhanced security of energy supply. On the other hand, the interest in adopting ISO standards, in general, is higher 
MMCKS in Europe than in other regions, as the standards are designed to address the needs of the organizations particularly in these parts of the world.

Table 1. ISO 50001 certificates worldwide

\begin{tabular}{|l|r|r|r|r|}
\hline Year & $\mathbf{2 0 1 1}$ & $\mathbf{2 0 1 2}$ & $\mathbf{2 0 1 3}$ & $\mathbf{2 0 1 4}$ \\
\hline TOTAL & $\mathbf{4 5 9}$ & $\mathbf{2 2 3 6}$ & $\mathbf{4 8 2 6}$ & $\mathbf{6 7 7 8}$ \\
\hline Africa & 0 & 13 & 36 & 18 \\
\hline Central/South America & 11 & 10 & 34 & 63 \\
\hline North America & 1 & 9 & 34 & 85 \\
\hline Europe & 364 & 1,919 & 3,993 & 5,526 \\
\hline East Asia and Pacific & 49 & 191 & 478 & 698 \\
\hline Central and South Asia & 26 & 76 & 189 & 299 \\
\hline Middle East & 8 & 18 & 62 & 89 \\
\hline
\end{tabular}

Source: ISO Survey 2014, www.iso.org.

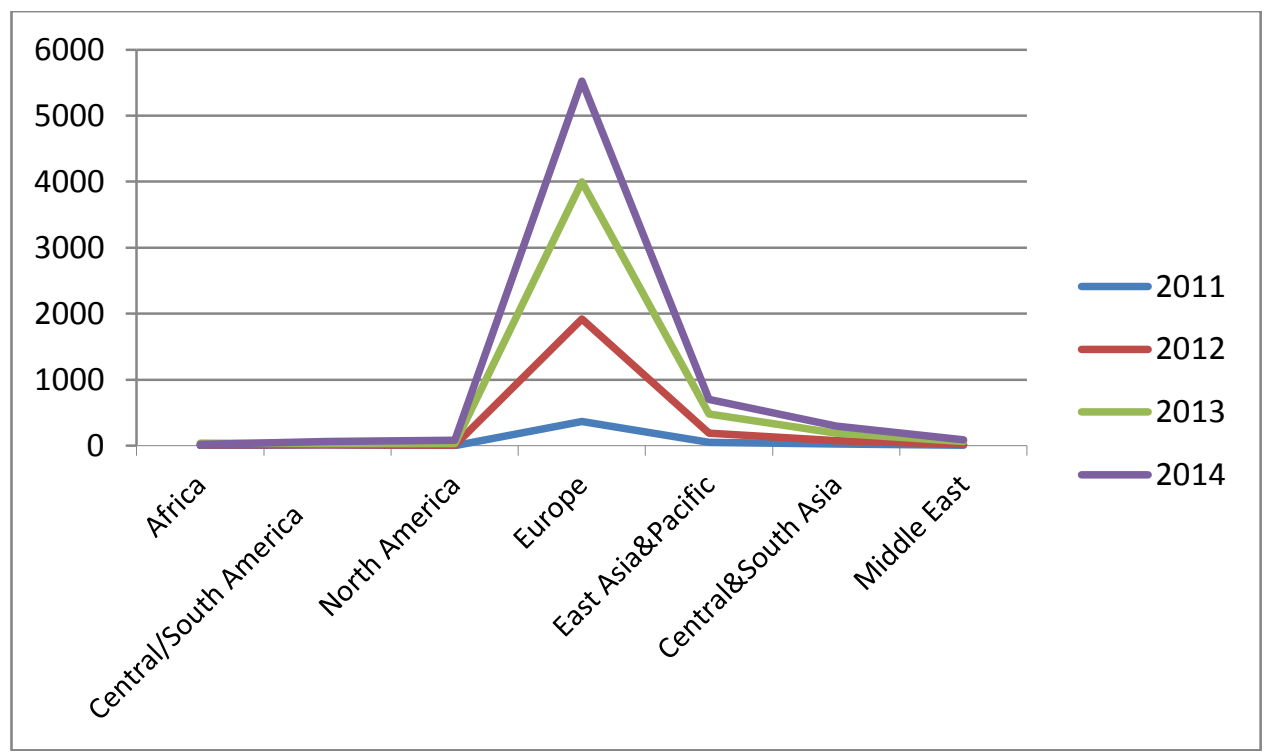

Figure 1. ISO 50001 certificates trend lines worldwide

Source: Authors' own research, processed based on ISO Survey 2014.

The distribution of ISO 50001 certificates achieved by organizations in different European countries is shown in Figure 2. As it is displayed in the figure, the trend lines for majority of the countries is increasing, and this growth is significant in countries like Italy, France, Slovenia, Spain or United Kingdom. However, the trend line for Romania is slightly decreasing from 2011 to 2014. This can be explained by both lack of awareness regarding energy use and environmental performance of the enterprise and also the high costs required by the energy management system implementation.

As it is shown in Table 2, the top ten countries ranked worldwide in 2014 for ISO 50001 certificates is predominantly consisted of countries coming from Europe, with Germany ranking first and a dominant position. Other European countries included in the ranking are United Kingdom, Spain, Italy, France and Austria. 


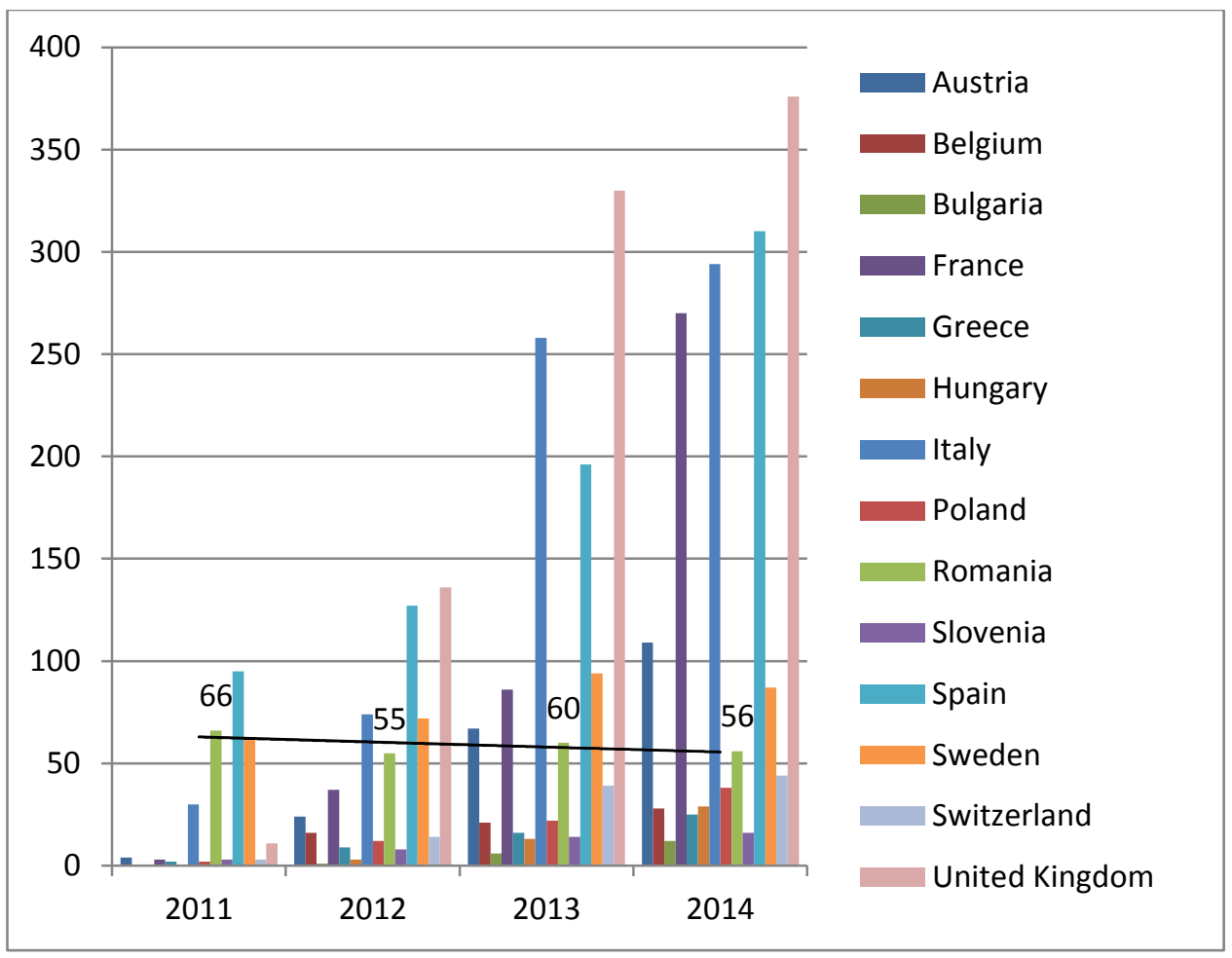

MMCKS

Figure 2. ISO 50001 certificates in Europe (without Germany)

Source: Authors' own research, processed based on ISO Survey 2014.

Table 2. Top 10 countries worldwide for ISO 50001 certificates - 2014

\begin{tabular}{|r|c|c|}
\hline \multicolumn{3}{|c|}{ Top $\mathbf{1 0}$ countries for ISO 50001 certificates } \\
\hline 1 & Germany & 3402 \\
\hline 2 & United Kingdom & 376 \\
\hline 3 & Spain & 310 \\
\hline 4 & Italy & 294 \\
\hline 5 & India & 271 \\
\hline 6 & France & 270 \\
\hline 7 & Taipei, Chinese & 176 \\
\hline 8 & Thailand & 168 \\
\hline 9 & Austria & 109 \\
\hline 10 & Korea, Republic of & 102 \\
\hline
\end{tabular}

Source: ISO Survey 2014, www.iso.org.

Practice shows that implementation of an energy management system gives customers, employees, top management and all stakeholders more confidence that the enterprise cares about energy, is committed to improve its energy performance and, actually, saves energy (Federal Ministry for the Environment, Nature Conservation and Nuclear Safety - BMU, 2012). Also, already existing management structures developed through implementation of different ISO models of performance management support the organizations to integrate energy management.

According to ISO Survey 2014, Romanian organizations manifest a relatively large interest in implementing the ISO models of performance management (either we refer to quality management system, environment management system, food safety management system or information security management system), with a continuous 
increasing trend line for each ISO model of performance management (see Table 3 and Figure 3).

Table 3. ISO certificates in Romania

\begin{tabular}{lrrrrrrrrrr}
\hline \multicolumn{1}{c}{ Year } & $\mathbf{2 0 0 5}$ & $\mathbf{2 0 0 6}$ & $\mathbf{2 0 0 7}$ & $\mathbf{2 0 0 8}$ & $\mathbf{2 0 0 9}$ & $\mathbf{2 0 1 0}$ & $\mathbf{2 0 1 1}$ & $\mathbf{2 0 1 2}$ & $\mathbf{2 0 1 3}$ & $\mathbf{2 0 1 4}$ \\
\hline ISO 9001 & 6097 & 9426 & 9633 & 10737 & 15865 & 16200 & 14345 & 18014 & 18450 & 18987 \\
\hline ISO 14001 & 752 & 1454 & 2269 & 3884 & 6863 & 7418 & 7394 & 8524 & 8744 & 9302 \\
\hline ISO 13485 & 4 & 2 & 9 & 8 & 28 & 56 & 109 & 97 & 96 & 64 \\
\hline ISO 16949 & 6 & 115 & 155 & 181 & 194 & 209 & 217 & 229 & 253 & 282 \\
\hline ISO 22000 & - & - & 276 & 347 & 661 & 641 & 698 & 996 & 1014 & 1130 \\
\hline ISO 27001 & - & 4 & 16 & 44 & 303 & 350 & 575 & 866 & 840 & 893 \\
\hline ISO 50001 & - & - & - & - & - & - & 66 & 55 & 60 & 56 \\
\hline
\end{tabular}

Source: ISO Survey 2014, www.iso.org.

\section{Legend:}

ISO 9001 - Quality management systems - Requirements

ISO 14001 - Environmental management systems - Requirements with guidance for use

ISO 13485 - Medical devices. Quality management systems - Requirements for regulatory purposes

ISO 16949 - Quality management systems - Particular requirements for the application of ISO 9001 for automotive production and relevant service part organizations

ISO 22000 - Food safety management systems - Requirements for any organization in the food chain ISO 27001 - Information technology. Security techniques - Information security management systems

- Requirements

ISO 50001 - Energy Management - Requirements with guidance for use

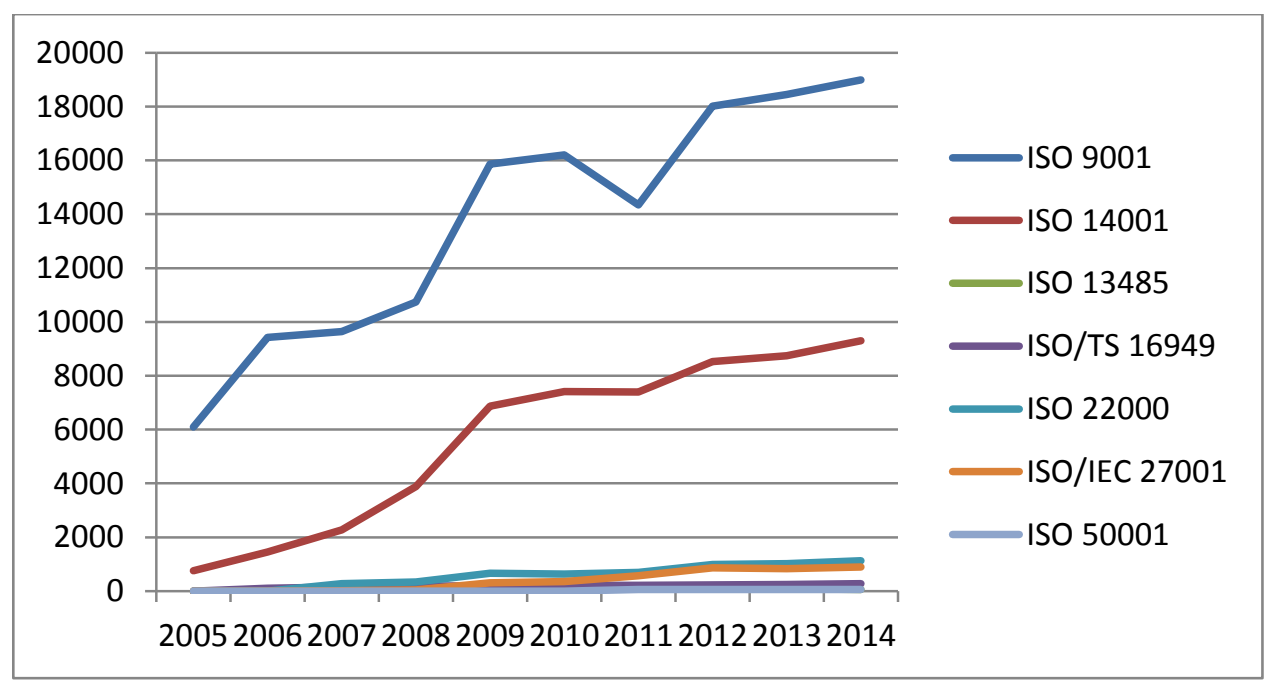

Figure 3. ISO certificates trend lines in Romania

Source: Authors' own research, processed based on ISO Survey 2014.

Also, in comparison with other European countries, Romanian organizations acknowledge great benefits as results of achieving ISO 50001 certification, manifested through the large interest shown for adopting the standard, since its development in 2011 (Figure 4). At OMV Petrom, for example, the main benefits of achieving certification of their energy management system include: enhanced security of energy supply, commenced processes to reduce energy risk exposure in different areas, continual improvement of operational efficiencies and maintenance practices, reduced greenhouse-gas emissions and carbon footprint, additional cost savings over the years, overall improved energy performance. 

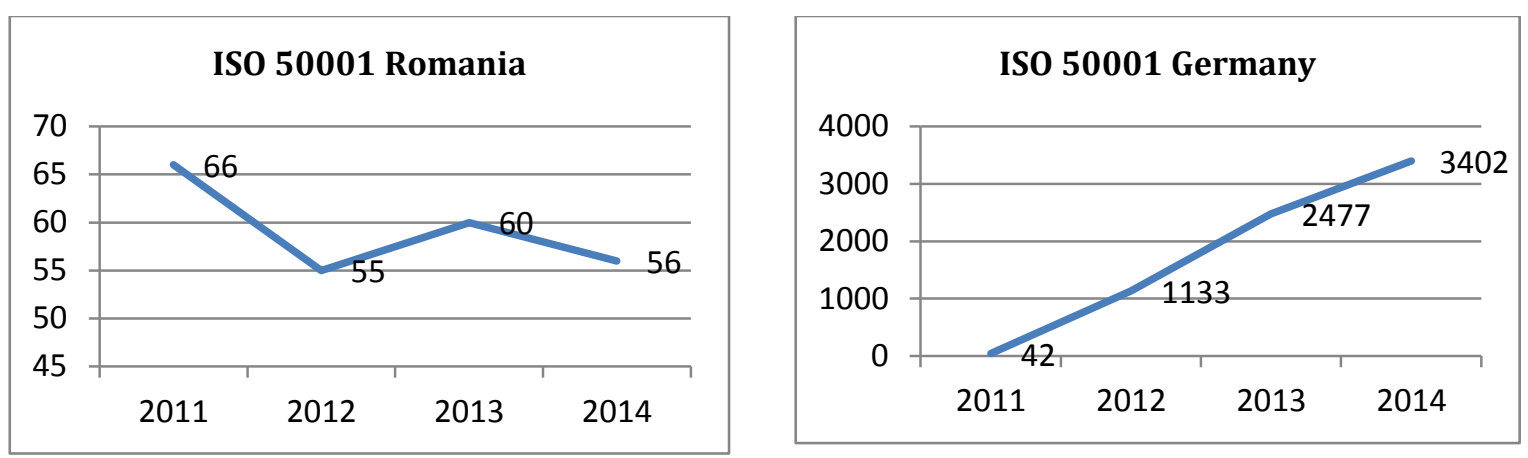

Figure 4. ISO 50001 certificates in Romania vs. Germany

Source: Authors' own research, processed based on ISO Survey 2014.

Although, Germany dominates from distance the worldwide ranking in what concerns the number of ISO 50001 certificates achieved by organizations and the trend line is rapidly increasing.

\section{Methodology}

The paper builds on the energy management system literature and uses an interpretation of the ISO 50001 and ISO 50004 energy management standards to address the gap that persists between theory and current energy management implementation practices in enterprises. Recent studies (Antunes et al., 2014; Brown and Desai, 2014; Gopalakrishnan et al., 2014) have started to build on the ISO 50001 standard requirements and proposed different energy management models that can be used to guide organizations in their energy management efforts to incrementally achieve compliance with the standard. Thus, following this approach, the essential steps that the enterprises should take to practically design a sustainable energy management system are presented.

Also, the paper employs multiple case study analysis of enterprises that have implemented an ISO 50001 energy management system, to develop a structured approach that companies can use to effectively develop their energy planning and improve energy performance. Enterprises have been selected from a broad range of industries: natural stone production, retail clothing, design and consultancy services for buildings, electricity and natural gas supply, and food retail. The existing literature on energy planning and improving energy performance provides evidence particularly in the manufacturing sector (e.g., Javied et al., 2015; Gopalakrishnan et al., 2014). Thus, the key components of the enterprises energy planning were analyzed, as well as their energy objectives and performance indicators have been scrutinized.

\section{Applying the ISO 50001 energy management system to an enterprise}

An ISO 50001 energy management system, like all the ISO management systems, works on the Plan-Do-Check-Act cycle, meaning (ISO 50001:2011; ISO 50004:2014): a) understand energy management basics, communicate benefits and get commitment of senior leadership, b) define an energy policy and create the energy team, c) conduct an energy review, which involves analyzing energy data, identifying areas of significant energy use and areas for energy performance improvement, d) establish an energy baseline, e) establish energy objectives and targets that are measureable and 
have timelines for achievement, f) establish an action plan to achieve energy objectives and targets, g) allocate resources and implement the action plan, h) check performance and take corrective, preventive and improvement actions, i) monitor, document and report results (Figure 5). Recent studies (Jovanović and Filipović, 2016; Antunes et al., 2014; Introna et al., 2014) build on the Plan-Do-Check-Act approach for continual improvement and propose an energy management maturity model that can help organizations achieve more efficiently compliance with ISO 50001 standard.

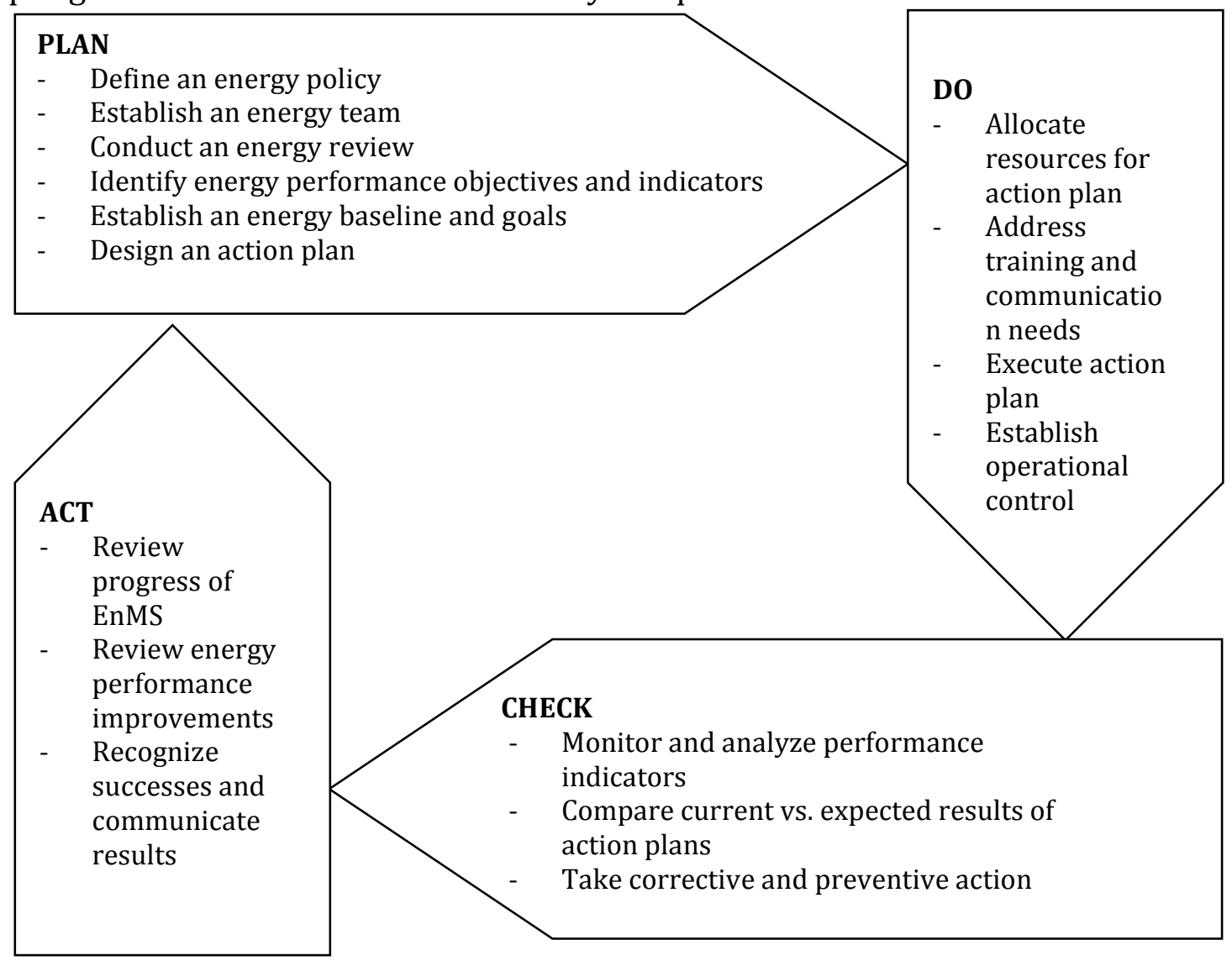

Figure 5. PDCA cycle for energy management

Source: Authors' own research, based on ISO 50001.

Even though the ISO 50001 energy management system was designed to suit almost any organization irrespective of its type, size, complexity or industry, applying it to an enterprise is quite a unique process.

The most important step in ISO 50001 implementation is the commitment stage. In this stage the benefits of implementing the standard are identified and communicated to top management. It is vital that top management clearly understands the benefits of ISO 50001 and commits to it by creating an energy policy stating the enterprise's commitment to the continual improvement of energy performance. The energy policy must also comply with any legal and other requirements expected of the enterprise. A management representative then needs to be appointed, with appropriate skills and competency, needed to carry out the required tasks in managing and improving the energy management system. The energy manager selects and forms successfully the enterprise's energy team. 
Once the commitment to the EnMS has been established, a review of the activities which may affect the energy performance must be undertaken. An energy review is a process to determine an enterprise's energy performance based on existing data, actual measurement and/or predictions, leading to identification of opportunities for improvement on energy performance. During the energy review several things need to be identified: current energy sources, past and present energy consumption, significant energy users, their energy performance indicators and opportunities for improving energy performance. By analyzing the enterprise's energy consumption data, trends and patterns in energy use can be identified and a profile of energy use can be created and from that, a baseline can be set. This baseline then becomes the benchmark for measuring changes in energy performance. In setting the energy baseline, the following elements should be taken into account: the initial energy status before the start of implementing the EnMS, expressed through energy need or consumption, physical and technical state of installations/ equipment/ buildings and uses of energy; an estimate of energy consumption as a result of measures to improve or action plans; changes which will appear in the sector of energy distribution as well as at the final consumer.

Next stage is energy planning when the enterprise establishes, implements, and maintains documented energy objectives and targets. These objectives should be measurable, realistic and achievable within a set time frame. It is important that the objectives and targets be approved by top management and communicated to those who may have an impact on them. They must also be reviewed on a regular basis. Then, an energy action plan will be established to show how these objectives and targets will be achieved. The energy action plan will be the main charter for the energy management system, and great attention must be given to the allocation of resources when trying to successfully implement the energy action plan.

Next stage refers to implementing the energy action plan. Special attention should be done to defining competence, communication, documentation, operational control, design, and procurement of energy services, equipment and energy. During the energy plan implementation, a training needs analysis should be undertaken for all persons who have an effect on significant energy users. Awareness in training is very important with respect to the energy policy, objectives and targets, and the potential consequences of personnel failing to follow procedures, which may lead to significant deviations in energy performance.

Documentation is a key component of any EnMS. It is the process of developing, implementing and maintaining procedures to control the EnMS documentation. The enterprise must ensure that these documents are approved, reviewed, updated, and any changes or revisions are clearly identifiable.

The next stage is the review of EnMS which has two parts: checking and the management review (both clearly defined in the ISO 50001 standard). The purpose of checking is to ensure that key characteristics which determine energy performance are monitored, measured and analyzed at planned intervals. For example, an enterprise should carry out and record internal audits at planned intervals so as to ensure that the EnMS conforms to the ISO 50001 standard. Also, activities necessary to improve the EnMS are carried out at planned intervals and are effective in enhancing the EnMS's ability to improve its energy performance. The result of the 
internal audit will be a non-conformities, correction, corrective action and preventive action plan.

Also, top management review is meant to show the current status of the enterprise's EnMS to determine if it is suitable, adequate and effective in managing the enterprise's energy performance. It closes the loop, allowing the cycle to repeat with renewed commitment from top management to the energy management process (Scheihing et al., 2013).

\section{Designing an effective energy planning to meet demands for energy performance indicators}

Energy planning

According to the ISO 50001 standard, energy planning, as integrative part of an energy management system, addresses specifically the following requirements: a) legal and other requirements applicable to the organization's energy uses, b) energy review, c) energy baseline, d) energy performance indicators (EnPIs), e) energy objectives and targets, and f) energy management action plans.

The purpose of energy planning is to highlight opportunities for improving energy performance in the fields with significant energy consumption (e.g., equipment, processes having the highest proportion in the total energy consumption or offering the maximum potential for saving energy). Opportunities for improvement are ranked according to their influence on energy efficiency. Energy management planning also forces the enterprise to identify and analyze which factors and variables affect its energy use at the level of entire organization, each business unit, a facility, or even an individual process or functional group, and to take action accordingly.

Energy planning can be done at different levels of an enterprise, depending on the size and structure of the business. It can be developed for an entire organization, a business unit, a facility, or even an individual process or functional group.

By taking into account the energy management framework introduced in the paper, an effective energy planning process requires consideration of the following steps (ISO 50001:2011): investigation and testing of existing energy management system implementation; defining the energy policy; analysis of energy usage; estimation of expected energy usage; identification of areas for potential improvement on energy performance; identification of all persons and their activities which affect total energy usage; accounting for compliance with legal requirements on energy; determination of responsibilities for energy management; development of energy baseline; development of measurable, documented and (within a time frame) achievable energy goals and targets; development of energy action plans.

Thus, the enterprise should demonstrate that it creates an energy policy which complies with applicable legislation and other requirements related to energy use, consumption and efficiency to which it subscribes. Also, the enterprise should record and maintain an energy review with certain documented methodology and criteria. As result of the energy review, an enterprise will create its energy profile (an example is given in Figure 6). The energy profile provides useful information for the development of the energy baseline and the identification and selection of energy performance indicators. 


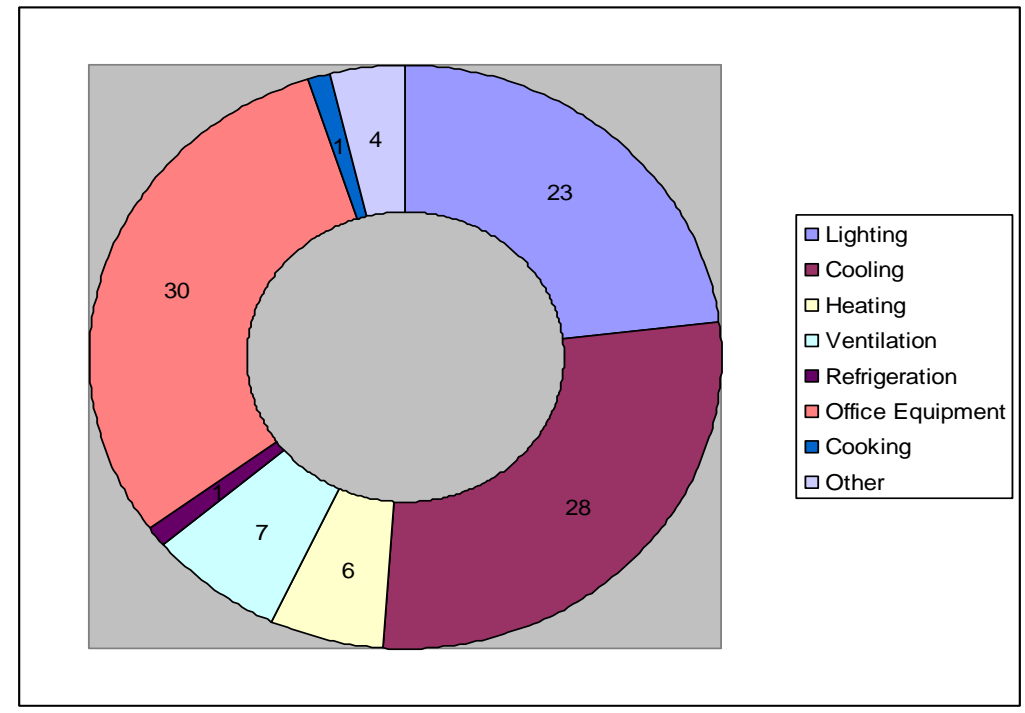

Figure 6. Energy profile for an organization

Source: Authors' own processing.

Documented energy objectives and targets should be established to ensure compliance with the enterprise's energy policy, to help enterprises use more efficiently energy, and to facilitate continual improvement in energy performance. Objectives should state what the enterprise wants to achieve; while targets should specify how the enterprise would achieve those objectives. The objectives and targets should be practical, achievable and measurable, and should conform to the enterprise's business objectives, as shown in Table 4.

Table 4. Energy objectives and targets

\begin{tabular}{|c|c|c|}
\hline Objectives & Targets & Actions \\
\hline $\begin{array}{l}\text { Reduce energy } \\
\text { consumption by } \\
\text { reviewing and improving } \\
\text { overall operations, } \\
\text { processes and activities } \\
\text { by } 20 \mathrm{xx}\end{array}$ & $\begin{array}{l}\text { Establish and implement by } \\
\text { the end of } 20 x x \text { a training } \\
\text { system for employees to } \\
\text { convey their roles in the } \\
\text { EnMS so as to contribute to } \\
\text { the improvement of } \\
\text { operations, processes and } \\
\text { activities }\end{array}$ & $\begin{array}{l}\text { Organize/outsource, by the energy } \\
\text { management team, an online training } \\
\text { program on energy performance for } \\
\text { activities and processes' optimization. } \\
\text { Inform regularly by emails or posters about } \\
\text { the fundamentals of the EnMS and overall } \\
\text { roles and responsibilities of all employees. }\end{array}$ \\
\hline $\begin{array}{l}\text { Comply with the energy } \\
\text { efficiency provisions } \\
\text { stipulated by Law no. } \\
121 / 2014 \text { on energy } \\
\text { efficiency by } 20 x x\end{array}$ & $\begin{array}{l}\text { Increase energy efficiency } \\
\text { for the building by } 3 \% \text { in } \\
\text { accordance with Law no. } \\
121 / 2014 \text { on energy } \\
\text { efficiency }\end{array}$ & $\begin{array}{l}\text { Reduce energy consumption for heating } \\
\text { with } 30 \% \text { by enveloping the building }\end{array}$ \\
\hline
\end{tabular}




\section{MMCKS}

524

\section{Implement an energy} monitoring system and monitor and evaluate energy performance 1
Reduce electricity

consumption by $30 \%$ by

20xx

Reduce energy consumption

for space heating and

cooling by $30 \%$ by $20 x x$

Reduce energy consumption

for heating by using smart

heating systems
Purchase only energy efficient equipment and materials - sensor lighting and led light bulbs, energy efficiency class A+ or above devices.

Purchase energy saving air conditioners with efficiency compressors, A ++ efficiency class

Building refurbishment (windows replacement, building insulation, optimization of air-flow equipment) by 20xx

Reduce the carbon footprint and enable recycling
Implement a waste and recycling management system by $20 x x$
Replace all traditional garbage bins with recycling bins on each floor of the building by the end of 20xx and replace nonessential printed documents by electronic ones to reduce the amount of printed paper

When setting energy objectives and EnMS targets, the following elements shall be taken into consideration: the energy policy; the results of the energy analysis and opportunities for hierarchical improvement; proposals for improving energy efficiency; new investments/projects; legal and other applicable requirements; statistical data regarding energy use, energy consumption and energy efficiency specific to the working point/ business unit and the associated impact. Energy policies and objectives should be aligned with existing business priorities and objectives. Also, these should be a key component of an enterprise's continuous improvement efforts.

Furthermore, action plans should be developed to address all of the enterprise's energy objectives and targets, detailing how and when they are to be achieved, which will subsequently facilitate monitoring the progress in achieving the energy objectives and targets. The action plans should include schedules, resources and responsibilities for achieving the objectives and targets and expected impact. An example of an action plan is given in Table 5 .

Table 5. Action plan: Reduce energy consumption inside the company

\begin{tabular}{ll}
\hline Concerns & Lighting in office building \\
\hline Target & $\begin{array}{l}\text { To reduce the energy consumption for lighting by } 10 \text { per cent } \\
\text { next year }\end{array}$ \\
\hline Parameters & $\begin{array}{l}\text { Energy consumption for lighting per employee in } \\
\text { [kWh/employee] }\end{array}$ \\
\hline Reference parameter & Yearly consumption \\
\hline Required investment & 700 euro \\
\hline Value of savings & Approx. 414 euro/year \\
\hline Pay-back time & Approx. 1,5 years \\
\hline Avoided CO2-emisson & 3.198 kg/year \\
& 1.Building awareness of the use \\
& 2.Stocktaking-review of lighting power at work places \\
& 3.Using energy saving lamps \\
\hline Time frame & 4.Optimized positioning of lamps \\
\hline
\end{tabular}

Vol.11, No. 3, Autumn, pp. 513-531 ISSN 1842-0206 | Management \& Marketing. Challenges for the Knowledge Society 


\begin{tabular}{ll}
\hline & 2. Until October 20xx \\
& 3. Until November 20xx \\
& 4. Until November 20xx \\
\hline Person responsible, amount of work & 1. Energy Manager -0.5 days \\
& 2. Company Tehnician-1.5 days \\
& 3. Company Tehnician-1 day \\
& 4. Energy Manager-0.5 days \\
\hline Provision of expenditures & By energy efficiency team budget \\
\hline Loss of work/production & None \\
\hline Others & Reworking the lighting affects the working atmosphere \\
& positively \\
& The durability of energy lamps is higher than the traditional \\
& lighting devices. \\
\hline
\end{tabular}

Source: Internal sources of the company.

Thus, an effective energy planning will help the enterprise to: review energy use, consumption and efficiency at defined intervals; document the methodology and criteria used to develop the energy review considering facilities, equipment, systems, processes or individuals; establish an energy baseline; identify energy performance indicators appropriate for monitoring and measuring it's energy performance; establish, implement and maintain documented energy objectives and targets; continually improve energy performance, including energy efficiency, energy use and consumption. The key components of energy performance are further discussed in the paper.

\section{Energy performance}

In the paper we argued that the main purpose of adopting an energy management system is to enable an enterprise to improve its energy performance. Energy performance includes the following components (ISO 50001:2011): energy efficiency, energy consumption, and energy use. These key components are defined below.

Energy efficiency is about energy security and care for the future. It has the goal to reduce the amount of energy required to provide products and services, to use less energy to provide the same energy service.

Energy consumption refers to the number of kilowatt-hours measured periodically from every energy source. Both energy consumption and energy efficiency classes depends for example on: building size, degree of isolation, and exploitation of the building. Energy consumption is computed by using the following formula: the energy (E) in kilowatt-hours $(\mathrm{kWh})$ per day is equal to the power $(\mathrm{P})$ in watts (W) times number of usage hours per day $(\mathrm{t})$ divided by 1000 watts per kilowatt (from every energy source):

$$
E(\mathrm{kWh} / \text { day })=P(\mathrm{~W}) \times t(\mathrm{~h} / \text { day }) / 1000(\mathrm{~W} / \mathrm{kW})
$$

Energy use is measured in relation with each energy source: fossil fuels (coal, oil, and gas), nuclear power, renewable energy (hydroelectricity, wind power, solar energy, geothermal, biomass and biofuels, marine and hydrokinetic (MHK) energy. To achieve the desired efficiency improvements, energy use should be measured in more detail and in real-time, to derive an awareness of the energy use patterns of every part of the enterprise. (Vikhorev et al., 2013).

Teixeira et al. (2016) propose an energy performance indicators matrix that allows the evaluation and monitoring of energy use, energy consumption and energy

Vol.11, No. 3, Autumn, pp. 513-531 ISSN 1842-0206| Management \& Marketing. Challenges for the Knowledge Society 
costs, leading to the identification of opportunities for energy performance improvement in municipalities. Their methodology for the development of the indicators relies on the integrated energy, quality and environment management systems. Thus, the energy performance indicators can be categorized as follows:

a) Total energy consumption of a facility. This refers to the total amount of energy consumed by the facility. It depends on the size of department, numbers of employees, workspace size, and energy efficiency of the building. Value for these indicators are obtained from meters, control instruments measurements and data reported in monthly invoices.

b) Specific energy consumption. This is calculated as the ratio of total energy consumption of the activity measured in energy units/ activity unit. Energy performance indicators include: specific energy consumption for lighting (total electric energy consumed (KW/year)/surface area); specific consumption for heating (total natural gas consumed $\left(\mathrm{m}^{3} /\right.$ year)/surface area); specific consumption for cooling (total electric energy consumed (KW/year)/surface area); specific consumption of other equipment (total electric energy consumed (KW/year)/surface area). These indicators are calculated based on aggregated data and are commonly calculate on yearly basis. They serve to measure and monitor the energy efficiency over time.

c) Energy intensity indicator or intensity index. The energy intensity indicator (EI) of a business unit or facility compares its actual energy consumption with the consumption of a reference facility with the same characteristics and activity.

$\mathrm{EI}=$ Real Energy Consumption year/Reference Energy Consumption year

or

EI $=$ Specific Consumption year/Reference Specific Consumption year

This indicator shows how the actual specific energy consumption of activity improved or worsened compared with a base year. A periodic monitoring of this indicator is required. Table 6 shows various examples of energy objectives and corresponding performance indicators as they are defined by the companies.

As such, by establishing an effective energy planning system, this will efficiently meet demands for achieving energy performance indicators and improving energy efficiency (Chiu et al., 2012).

Table 6. Energy objectives and performance indicators

Company: $\mathrm{ABC}$

Industry: Natural stone production

The domain of applicability of ISO 50001: Cutting, shaping and finishing of natural stone using highest technologies and equipment

Energy objectives $\quad$ Energy performance indicators

Company: XYZ

Industry: Retail clothing

The domain of applicability of ISO 50001: Textiles - renewable energy, machines, recycling waste, development of alternate fibers sources for man-made cellulosic fabrics

Energy objectives Energy performance indicators

- To reduce operation's total greenhouse gas • $\quad$ Energy usage in gigajoules (stores, offices emissions by end of 20xx while growing 9\%etc.);

Vol.11, No. 3, Autumn, pp. 513-531 ISSN 1842-0206 | Management \& Marketing. Challenges for the Knowledge Society 
$13 \%$ annually;

- Reduction in energy consumption per square meter with $25 \%$ by $20 x x$ in stores, offices and warehouses, by using LEED lights;

- Reduction in energy consumption during manufacturing processes - colder water for washing leads to a reduction of $60 \%$ in energy consumption.
- $\quad$ CO2 emission;

- Tones of water consumption and water savings;

- $\quad$ Percent of renewable energy used;

- $\quad$ Tones of garments and waste recycled;

- $\quad$ Percent of energy savings;

- Percentage of reduction $\mathrm{CO} 2$ in value chain.

Company: UVW

Industry: Design and consultancy services for buildings

The domain of applicability of ISO 50001: Design and consultancy services for buildings

\section{Energy objectives}

\section{Energy performance indicators}

- $\quad$ Purchase of energy efficient products (Class A or higher) when replacements of equipment are necessary;

- Designing solutions to lower energy consumption for lighting, heating, cooling at the company in the next year and their implementation in the coming years;

- Introducing equipment that uses renewable energy systems at the company's facilities in more than 4 years;

- Reducing energy consumption for lighting with $2.5 \%$ by changing the work schedule accordingly with the natural light availability;

- Reducing energy consumption for lighting with $2.5 \%$ by installing presence sensors in restrooms and kitchen;

- $\quad$ Reducing energy consumption for lighting with $6 \%$ by using LED light sources for permanent occupied desks.
MMCKS

527 $\bullet$

Specific energy consumption for lighting (electric kWh/sqm*year);

- $\quad$ Specific energy consumption for heating (electric kWh/sqm*year);

- $\quad$ Specific energy consumption for cooling (electric kWh/sqm*year).

Company: OPR

Industry: Electricity and natural gas supply

The domain of applicability of ISO 50001: Electricity production and electricity supply to the entire firm portfolio of final consumers

\section{Energy objectives Energy performance indicators}

- Reduce invertors DC electricity consumption • Total electricity production per square by $15 \%$ until end of $20 x x$; meter of installed PV panel;

- Reduce energy consumption for lighting by - Total electricity use of invertors; $10 \%$ until end of 20xx;

- Increase electricity production by $20 \%$.

- Total electricity use for nocturnal illumination and supervisory activities.

Company: LMN

Industry : Food retail

The domain of applicability of ISO 50001: The entire retail area (offices and stores), coffeehouses, equipment.

- Reduce energy consumption by $20 \%$ in the • Direct energy consumption by primary company -operated stores by 20xx; energy source;

- Purchase renewable energy equivalent to - Energy saved due to conservation and

Vol.11, No. 3, Autumn, pp. 513-531 ISSN 1842-0206 | Management \& Marketing. Challenges for the Knowledge Society 
$100 \%$ of the electricity used in the global company-operated stores by $20 x x$;

- Reduce the water consumption by $20 \%$ in all operated stores by $20 x x$;

- Build all new, company-owned stores to achieve LEED certificate by $20 x x$. efficiency improvements;

- Initiatives to provide energy efficient or renewable energy based on products and services, and reductions in energy requirements as a result of these initiatives.

Source: Authors' research based on internal sources of the companies

\section{Conclusion}

When implementing ISO 50001 it is of crucial importance that top management understands the importance of energy performance development and gives their full commitment to its implementation.

The current paper discussed the essential steps the enterprises should take to practically design a sustainable energy management system, by using the Plan-DoCheck-Act approach. It described the approach that the enterprises should use to effectively develop and implement their energy planning and improve energy performance, starting from energy review, accounting for compliance with energy legislation, up to developing energy action plans. In the paper we exemplified how the enterprises establish their energy objectives and targets and how they define the energy performance indicators. An example of an action plan on reducing energy consumption was also offered.

One of the main challenges faced by enterprises in the process of energy management system implementation is the balancing act the energy team had to play between implementing ISO 50001 and their other primary duties/roles in the enterprise. Changing the status quo and convincing middle level managers and the entire personnel to invest in training, resources and technology that would improve energy efficiency is another significant challenge. Also, identifying significant energy users and their relevant variables is a crucial element.

While setting objectives towards energy performance improvement and energy savings, it is very important for the enterprise to develop a strong measurement and analysis plan in order to ensure an easy implementation, while verifying that the results are up to the initial planned expectations.

The energy objectives and performance indicators prove to be excellent instruments for achieving reliable data models that are necessary in order to obtain superior energy performance in the enterprise's (Scheihing et al., 2013). Also, the enterprise can successfully break down and compare specific energy performance indicators in order to help meet energy and environment targets.

The paper contributes to a better understanding of practicability of energy

planning in an enterprise and supports energy managers and energy teams in their efforts to design an appropriate energy management system in their organizations. However, we should mention that the budget to invest in energy efficiency programs each year must compete for priority with other important business objectives of the enterprise.

\section{Acknowledgement}

Special thanks are extended to the master's students of the Program of the Entrepreneurship and Business Administration in Energy, Faculty of Business 
Administration in Foreign Languages, for their contribution to the course on Energy Management Systems.

\section{Disclaimer}

A shorter version of this article was presented during the 10th International Conference on Business Excellence in Energy, Climate Change and Sustainability (ICBE) in Bucharest, Romania, on the 3rd of March 2016, and published in the conference proceedings.

\section{References}

Anisimova, T.Yu. (2013), "Analysis of standards in energy management", Middle-East Journal of Scientific Research, Vol. 13, No. 5, pp. 654-657.

Antunes, P., Carreira, P. and Silva, M.M.S. (2014), "Towards an energy management maturity model", Energy Policy, Vol. 73, No. 3, pp. 803-814.

Bonacina, F., Corsini, A., De Propris, L., Marchegiani, A. and Mori, F. (2015), "Industrial energy management systems in Italy: State of the art and perspective", Energy Procedia, Vol. 82, No. 4, pp. 562-569.

Brown, M. and Desai, D. (2014), “The ISO 50001 energy management standard", Strategic Planning for Energy and the Environment, Vol. 34, No. 2, pp. 16-25.

Chiu, T.Y., Lo, S.H. and Tsai, Y.Y. (2012), "Establishing an integration-energy-practice model for improving energy performance indicators in ISO 50001 Energy Management Systems", Energies, Vol. 5, No. 12, pp. 5324-5339.

Dzene, I., Polikarpova, I., Zogla, L. and Rosa, M. (2015), “Application of ISO 50001 for implementation of sustainable energy action plans", Energy Procedia, Vol. 72, No. 2, pp. 111-118.

Federal Ministry for the Environment, Nature Conservation and Nuclear Safety - BMU (2012), "Energy management systems in practice ISO 50001: A Guide for companies and organizations", Berlin, Germany, available at: https://www.adelphi.de/sites/default/files/mediathek/bilder/de/projekte/a pplication/pdf/energy-management-systems-in-practice_bmub-ubaadelphi.pdf (accessed Feb. 22, 2016).

Gopalakrishnan, B., Ramamoorthy, K., Crowe, E., Chaudhari, S. and Latif, H. (2014), “A structured approach for facilitating the implementation of ISO 50001 standard in the manufacturing sector", Sustainable Energy Technologies and Assessments, Vol. 7, pp. 154-165.

International Organization for Standardization (2011), "Win the energy challenge with ISO 50001", Geneva, Switzerland, available at: http://www.iso.org/iso/ iso_50001_energy.pdf (accessed Jan. 28, 2016).

International Organization for Standardization (2014), "ISO Survey 2014", available at: http://www.iso.org/iso/home/standards/certification/iso-survey.htm? certificate $=$ ISO\%209001\&countrycode=AF (accessed March 12, 2016).

International Organization for Standardization (2015), "ISO 50001 - Energy management systems - A practical guide for SMEs", Geneva, Switzerland, available at: http://www.iso.org/iso/50001_handbook_preview.pdf (accessed Jan. 28, 2016). 
ISO 50001:2011, "Energy Management Systems -- Requirements with guidelines for use", Geneva, Switzerland.

ISO 50004:2014, "Energy management systems -- Guidance for the implementation, maintenance and improvement of an energy management system", Geneva, Switzerland.

Introna, V., Cesarotti, V., Benedetti, M., Biagiotti, S. and Rotunno, R. (2014), "Energy Management Maturity Model: an organizational tool to foster the continuous reduction of energy consumption in companies", Journal of Cleaner Production, Vol. 83, No. 3, pp. 108-117.

Javied, T., Rackow, T. and Franke, J. (2015). "Implementing energy management system to increase energy efficiency in manufacturing companies", Procedia CIRP, Vol. 26, pp. 156-161.

Jovanović, B. and Filipović, J. (2016), "ISO 50001 standard-based energy management maturity model - proposal and validation in industry", Journal of Cleaner Production, Vol. 112, No. 1, pp. 2744-2755.

Karcher, P. and Jochem, R. (2015), "Success factors and organizational approaches for the implementation of energy management systems according to ISO 50001", TQM Journal, Vol. 27, No. 4, pp. 361-381.

Lee, D. and Cheng, C.C. (2016), "Energy savings by energy management systems: A review", Renewable and Sustainable Energy Reviews, Vol. 56, No. 2, pp. 760-777.

Majerník, M., Bosák, M., Štofová, L. and Szaryszová, P. (2015), "Innovative model of integrated energy management in companies", Quality Innovation Prosperity, Vol. 19, No. 1, pp. 22-32.

OGP/IPIECA (2013), "Guidelines for implementing ISO 50001 Energy Management Systems in the oil and gas industry", OGP Report Number 482, London, United Kingdom, available at: http://www.ogp.org.uk/pubs/482.pdf (accessed Jan. 22, 2016).

Pham, T.H.H. (2015), "Energy management systems and market value: Is there a link?", Economic Modeling, Vol. 46, pp. 70-78.

Scheihing, P.E., Almaguer, J.A., Reyes, P.B. and Fisher-Evans, T.E. (2013), "Superior Energy Performance $\mathrm{e}^{\mathrm{cm}}$ : A roadmap for continual improvement in energy efficiency", Strategic Planning for Energy and the Environment, Vol. 32, No. 3, pp. 39-55.

Schneider Electric (2012), "ISO 50001 Recommendations for compliance. White paper: March 2012", available at: http://static.schneiderelectric.us/docs/Power\% 20Management/Energy\%20Sustainability/ISO\%2050001\%20Consulting/Iso5 0001Recommendations.pdf (accessed Jan. 22, 2016).

Teixeira, M.R., Mendes, P., Murta, E. and Nunes, L.M. (2016), "Performance indicators matrix as a methodology for energy management in municipal water services", Journal of Cleaner Production, Vol. 125, No. 2, pp. 108-120.

The Hong Kong Electronic Industries Association - HKEIA (2013), “Guidebook for ISO 50001 Energy Management System", Tsim Sha Tsui East, Hong Kong, available at: http://www.hkeia.org/iso50001/eguidebook/ISO50001\%20guide_ENG\% 2019Aug(Final).pdf (accessed Jan. 21, 2016). 
TÜV UK Ltd (2013), "ISO 50001 Energy Management System (EnMS) Implementation guide", London, United Kingdom, available at: http://www.tuv-uk.com/cps/ rde/xbcr/SID-A25B9185102594DE/tng_uk/iso-50001-guide-and-check-list-uk.pdf (accessed Jan. 23, 2016).

Vikhorev, K., Greenough, R. and Brown, N. (2013), "An advanced energy management framework to promote energy awareness", Journal of Cleaner Production, Vol. 43, No. 1, pp. 103-112. 